\title{
Leukemia Inhibitory Factor Levels Are Elevated in Septic Shock and Various Inflammatory Body Fluids
}

\author{
Paul Waring, Kaye Wycherley, Dale Cary, Nicos Nicola, and Donald Metcalf \\ Cancer Research Unit, The Walter and Eliza Hall Institute of Medical Research, Melbourne, Victoria 3050, Australia
}

\begin{abstract}
Leukemia inhibitory factor (LIF) has many biological actions which parallel those of IL-1, IL-6 and tumor necrosis factor- $\alpha$, but its role in the pathogenesis of human disease is unknown. $A$ specific radioreceptor competition assay capable of detecting LIF at concentrations above $1 \mathrm{ng} / \mathrm{ml}$ (45 pM) was developed. To identify disease states in which LIF might be involved, a cross-sectional survey of serum and body fluids from $\sim \mathbf{1 , 5 0 0}$ subjects with a variety of diseases was performed using the LIF radioreceptor competition assay. Serum LIF concentrations were transiently elevated $(2-200 \mathrm{ng} / \mathrm{ml})$ in six subjects with meningococcal or Gram-negative septic shock, and in a subject with idiopathic fulminant hepatic failure. Moderately elevated LIF concentrations ( $>10 \mathrm{ng} / \mathrm{ml}$ ) were detected in cerebrospinal fluid from subjects with bacterial meningitis, in effusions associated with pneumonia and peritonitis, and in amniotic fluid from a woman with chorioamnionitis. Low LIF concentrations (1-10 $\mathrm{ng} / \mathrm{ml}$ ) were present in synovial fluid from subjects with inflammatory arthritis, amniotic fluid from women in labor, and some reactive, chronic inflammatory and malignant effusions and cyst fluids, but rarely in transudates. These initial findings suggest that LIF might be involved in the pathogenesis of inflammation and septic shock. (J. Clin. Invest. 1992. 90:2031-2037.) Key words: meningococcemia • meningitis • labor • chorioamnionitis • arthritis
\end{abstract}

\section{Introduction}

Elevated concentrations of several cytokines have recently been shown to be present in human body fluids in association with various diseases. The most prominent of these are IL- $1 \alpha$, IL-6, and tumor necrosis factor- $\alpha$ (TNF- $\alpha) .{ }^{1}$ These have been

Address correspondence to Dr. Paul M. Waring, The Walter and Eliza Hall Institute of Medical Research, PO Royal Melbourne Hospital, Melbourne, Victoria 3050, Australia.

Received for publication 24 February 1992 and in revised form 18 June 1992.

1. Abbreviations used in this paper: $B / B_{0}$, fraction bound ratio; $\mathrm{CHO}$, Chinese hamster ovary cells; G-CSF, granulocyte-colony stimulating factor; GM-CSF, granulocyte-macrophage colony-stimulating factor; LIF, leukemia inhibitory factor; LIFR, leukemia inhibitory factor receptor; M-CSF, macrophage-colony stimulating factor; OSM, oncostatin M; RHF, Hepes-buffered RPMI 1640 medium supplemented with $10 \%$ FCS; RRA, radioreceptor competition assay; SCF, stem cell factor (Steel factor); TGF, transforming growth factor; TNF, tumor necrosis factor.

J. Clin. Invest.

(C) The American Society for Clinical Investigation, Inc.

$0021-9738 / 92 / 11 / 2031 / 07 \quad \$ 2.00$

Volume 90, November 1992, 2031-2037 shown to be present at very low concentrations in serum from healthy people, and have been primarily implicated in mediating inflammatory reactions and septic shock (1-3). Many of the biological actions of these cytokines parallel those of a recently described growth factor, leukemia inhibitory factor (LIF), which was characterized by its ability to induce differentiation of the murine myeloid leukemic cell line, $M 1(4,5)$.

In common with IL-1 $\alpha$ (1), TNF- $\alpha(2)$, and IL-6 $(3,6)$, LIF stimulated acute phase protein synthesis by hepatocytes (7) and induced bone resorption (8). In addition, both IL-6 (3) and LIF induced neuronal (9) and myeloid leukemic cell differentiation (5), and have been implicated in early embryogenesis (10) and the regulation of megakaryocytopoiesis (11, 12). Like IL-1 $\alpha$ and TNF- $\alpha$ (2), LIF inhibited the activity of lipoprotein lipase in cells of the 3T3-L1 preadipocyte line (13), and LIF has been implicated in the induction of cachexia (14).

Molecular clones encoding the murine and human LIF receptors (LIFR) have been isolated (15), and a specific low affinity form identified. High affinity LIFR have been demonstrated to be present on several cell types including monocytesmacrophages, hepatocytes, osteoblasts, placental trophoblasts, and others (16-19). Conversion of low affinity to high affinity LIF receptor status appears to be conferred by a beta subunit (gp130), which is also the signal transducer for the IL-6 receptor and is the low affinity Oncostatin M (OSM) receptor (20).

Transcription of the LIF gene was detected, with the exception of the uterus during pregnancy, at low levels in normal adult tissues (21). However, LIF or its transcripts have been detected in vitro in many cell types, including fibroblasts, activated $\mathrm{T}$ lymphocytes, monocytes-macrophages, bone marrow stromal cells, osteoblasts, and astrocytes (17), endothelial cells (22), and in several human tumor cell lines $(13,23)$. Depending on the cell type, LIF production or transcription occurred spontaneously in vitro and could be induced or enhanced by various stimuli, including LPS, IL- $\alpha$ and $\beta$, TNF- $\alpha$, transforming growth factor- $\beta$ (TGF- $\beta$ ), T cell mitogens, phorbol 12 -myristate 13 -acetate, and retinoic acid (17). These findings suggest that LIF is an inducible cytokine capable of being produced by a wide variety of cells and tissues only when stimulated by appropriate stimuli, characteristics shared by other cytokines implicated in mediating inflammatory responses.

This article describes a specific radioreceptor competition assay (RRA) for the quantitation of biologically active LIF and the findings of a cross-sectional survey of serum and body fluids from $\sim 1,500$ subjects. The LIF RRA had the same sensitivity as the M1 bioassay that was previously used to measure LIF, but which proved not to be specific because other regulators, such as IL-6 (24), granulocyte-colony stimulating factor (G-CSF) (25), and OSM (26) were shown to induce differentiation in $\mathrm{M} 1$ cell colonies. We report that LIF is present in a variety of inflammatory fluids and is transiently present at high concentrations in the serum of some subjects with septic shock. 


\section{Methods}

Sample collection and preparation. Samples were obtained for diagnostic or therapeutic indications only and were collected prospectively from various diagnostic pathology laboratories of the Royal Melbourne Hospital, the Royal Women's Hospital, and the Royal Children's Hospital in Melbourne, Australia. Ethics committee approval was previously obtained from each hospital. Plasma from six subjects with myelofibrosis and 23 subjects with hypercalcemia was kindly provided by Drs. M. Martyré (Institut Curie, Paris, France) and V. Grill (St. Vincent's Hospital, Melbourne), respectively.

Plasma samples were prepared from ulood anticoagulated with either EDTA or lithium heparin. Plasma and viscous fluid samples were heat inactivated at $56^{\circ} \mathrm{C}$ for $30 \mathrm{~min}$ and synovial fluid was treated with hyaluronidase type IX (Sigma Chemical Co., St. Louis, MO) $(1 \mathrm{U} / \mathrm{ml}$ ) and DNAase GdII (Boehringer Mannheim GmbH, Mannheim, Germany) $(12.5 \mu \mathrm{g} / \mathrm{ml})$ at $37^{\circ} \mathrm{C}$ for $10 \mathrm{~min}$, each followed by centrifugation at $3,000 \mathrm{~g}$ for $10 \mathrm{~min}$. Samples cytotoxic to $\mathrm{M} 1$ cells were dialyzed through NAP-5 tubes (Pharmacia AB, Uppsala, Sweden) with an equal volume of $1 \%$ FCS (Commonwealth Serum Laboratories, Melbourne, Australia) in DME and reassayed.

Cytokines. Native human LIF was produced from the human bladder carcinoma cell line 5637 conditioned medium (5637-nhLIF), as described (27). Recombinant Escherichia coli murine (rmLIF) and human LIF (rhLIF) ( mol wt 22,000) and glycosylated baculovirus human LIF (BvhLIF) were kindly provided by AMRAD Corp., Melbourne, Australia. Glycosylated human LIF produced by chinese hamster ovary $(\mathrm{CHO})$ cells transfected with a high expression vector for human LIF (CHO-LIF) was kindly provided by Merck \& Co., Inc., Rahway, NJ. The above forms of LIF had specific activities of $10^{8}$ $\mathrm{U} / \mathrm{mg}$ of protein. Iodinated LIF ( ${ }^{125} \mathrm{I}$-rmLIF), which had a specific radioactivity of $450,000 \mathrm{cpm} / \mathrm{pmol}\left(0.22 \times 10^{-6} \mathrm{Ci} / \mathrm{pmol}\right)$ was produced by the iodine monochloride method and separated from free ${ }^{125} \mathrm{I}$ by chromatography using a 250- $\mu$ l column of CM-Sepharose (Pharmacia $\mathrm{AB}$ ), as described (19).

The following Escherichia coli recombinant human cytokines were used to test the specificity of the LIF RRA: G-CSF (Amgen Biologicals, Thousand Oaks, CA), granulocyte-macrophage-CSF (GM-CSF)(Sandoz AG, Basel, Switzerland), macrophage-CSF (M-CSF) (Cetus Corp., Emeryville, CA), IL-1 $\alpha$ (Hoffmann-La Roche, Nutley, NJ), IL-1 $\beta$ (Glaxo, Geneva, Switzerland), IL-2 (Cetus), IL-3 (Cetus), IL-6 (Sandoz), TNF- $\alpha$ and TNF- $\beta$ (Boehringer Ingelheim, Germany), TGF- $\beta$ (Ciba-Geigy AG, Basel, Switzerland) and Steel factor (rhSCF) (Amgen) (28). Recombinant human OSM was produced in yeast and was kindly provided by D. Gearing (Immunex, Seattle, WA), and IL-4 was produced in CHO cells and was kindly provided by A. Boyd (The Walter and Eliza Hall Institute, Melbourne).

Cell lines. Cells of the murine M1 leukemic and 3T3-L1 preadipocyte cell lines were used. M1 and 3T3-L1 cells were previously shown to possess $80-200$ and $1,000-1,500$ high affinity $\left(K_{d} \sim 30\right.$ pM $)$ LIFR/ cell respectively (29), and the latter were employed in the RRA due to the higher number of LIFR. Both were maintained in culture of $10 \%$ FCS/DME. The 3T3-L1 cells were passaged with trypsin-versene (Commonwealth Serum Laboratories) and harvested with EDTA (Ajax Chemicals, Auburn, Australia) (4 mM) and chondroitin sulphate A (Sigma Chemical Co.) $(0.2 \mathrm{~g} /$ liter $)$ both in Hepes-buffered RPMI 1640 medium supplemented with $10 \%$ FCS (RHF).

Radioreceptor competition assay ( $R R A$ ). LIF was detected by competition for ${ }^{125}$ I-LIF binding to the LIF receptors present on cells of the 3T3-L1 line. Volumes of $50 \mu \mathrm{l}$ of RHF were added to the sample and standard curve wells of 96-well U-vinyl plates (Costar Corp., Cambridge, MA) which had been precoated with RHF. 50- $\mu$ l vol of sample, or rmLIF used as a standard curve, were added in duplicate and titrated by serial twofold dilutions, and the volumes made up to $70 \mu \mathrm{l}$ by addition of $20 \mu \mathrm{l}$ RHF. The standard curve LIF concentrations ranged from $1 \mathrm{nM}$ to $2 \mathrm{pM}$. Volumes of $70 \mu \mathrm{l}$ of excess $\operatorname{rmLIF}(45 \mathrm{nM})$ in RHF served as a "total blocking" positive control and RHF alone was used as a "no blocking" negative control (Bo). A 20- $\mu$ l volume of 3T3-L1 cell suspension, containing $0.2 \times 10^{6}$ cells in $\mathrm{RHF}$, was then added to all wells. The plates were incubated overnight on ice, then $10 \mu \mathrm{l}$ of RHF containing $20,000 \mathrm{cpm}$ of ${ }^{125} \mathrm{I}$-rmLIF ( $330 \mathrm{pM}$, after correction for $80 \%$ bindability) (19) was added to each well. The plates were then incubated on ice for $1 \mathrm{~h}$, centrifuged at $3,000 \mathrm{~g}$ for $5 \mathrm{~min}$ at $4^{\circ} \mathrm{C}$, and the cells were washed three times in phosphate buffered saline. The plates were then exposed to phosphor screens for $\sim 24 \mathrm{~h}$, and were then read on a 400A Phosphorimager (Molecular Dynamics, Sunnyvale, CA) and the counts integrated using the ImageQuant version 3.0 software program (Molecular Dynamics). The integrated data were converted to a fraction bound $\left(B / B_{0}\right)$ ratio and the amount of LIF present calculated by comparison with the standard curve.

MI bioassay. When sample volumes permitted, M1 assays were performed on all samples that were positive for LIF by the RRA. The M1 assays were performed using in vitro semisolid agar cultures as described (5). Briefly, 100- $\mu$ l volumes of sample or standard rmLIF $(0.45 \mathrm{nM}$, in $5 \%$ FCS in isotonic saline $)$ in serial twofold dilutions were added in duplicate to $35-\mathrm{mm}$ petri dishes. Control cultures contained $100 \mu \mathrm{l}$ of $5 \% \mathrm{FCS}$ in isotonic saline. Cultures of $1-\mathrm{ml}$ volumes of DME containing 20\% FCS in $0.3 \%$ agar (Difco Laboratories, Detroit, MI) and $300 \mathrm{M} 1$ cells were added to each dish and incubated at $37^{\circ} \mathrm{C}$ in a fully humidified atmosphere of $10 \% \mathrm{CO}_{2}$ in air for $7 \mathrm{~d}$ and then scored. $50 \mathrm{U}$ was defined as the amount of activity which resulted in $50 \%$ of the colonies being differentiated.

Statistical analysis. Correlations between titers obtained with LIF RRA and M1 assays were analyzed using Pearson's correlation coefficient (30).

\section{Results}

Determination of $R R A$ specificity and sensitivity. The radioreceptor assay showed no inhibition of ${ }^{125} \mathrm{I}$-rmLIF binding to 3T3-L1 cells by the following recombinant human cytokines: G-CSF (2.25 nM), GM-CSF (35 nM), IL-1 $\alpha$ (0.28 nM), TNF- $\alpha(5 \mathrm{nM})$ or IL-6 (12.5 nM) (Fig. $1 \mathrm{~A})$. Similar negative results were obtained for M-CSF (1.2 nM), IL-1 $\beta(0.1 \mathrm{nM})$, IL-2 (18 nM), IL-3 (3.6 nM), IL-4 (31 nM), TNF- $\beta$ ( $5 \mathrm{nM}$ ), TGF- $\beta$ ( $0.4 \mathrm{nM}), \operatorname{SCF}(8.3 \mathrm{nM}$ ), and OSM ( $25 \mathrm{nM}$ ) (data not shown). The above concentrations are expressed as final concentrations and are those which result in supramaximal effects in their respective biological systems.

Native human LIF (5637-nhLIF), $E$. coli-derived rmLIF and rhLIF and glycosylated BvhLIF and CHO-LIF were detected with an equal sensitivity of $1 \mathrm{ng} / \mathrm{ml}(45 \mathrm{pM})$ (Fig. $1 B)$, equivalent to the sensitivity of the M1 assay (data not shown). The same sensitivity was obtained with rmLIF previously added to RHF, human serum or plasma and was not affected by heat treatment at $56^{\circ} \mathrm{C}$ for $30 \mathrm{~min}$ when measured by the RRA (Fig. $1 C$ ) and M1 assay (data not shown). Similar results were obtained with LIF added to synovial fluid then treated with hyaluronidase/DNAase (data not shown). LIF added to human serum then titrated in serum showed no loss of inhibition compared to samples titrated in RHF, indicating that there was no detectable inhibitory activity (data not shown). These data show that the RRA was capable of specifically detecting biologically active endogenous human LIF.

Assay results. Samples from 1,510 subjects were screened and quantitated by the LIF RRA (Table I). There was an overall concordance $(r=0.663)$ between the LIF concentrations measured by RRA and M1 assays (Fig. 2), although the titers were generally higher in the M1 assay.

Serum and plasma. Plasma or serum samples were collected nonrandomly from 494 subjects (Table II) whose clinical details were obtained either from the referring doctor or 


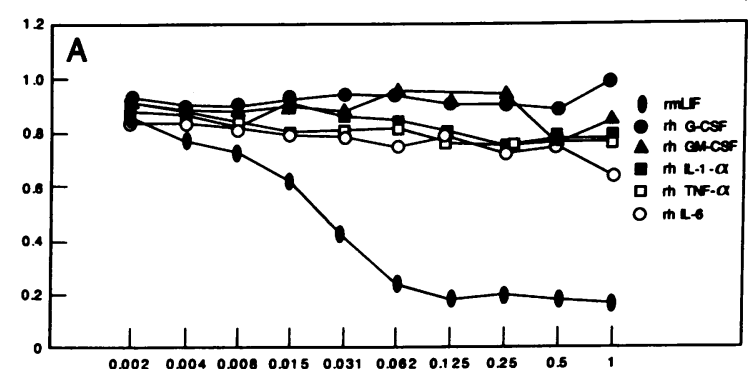

DILUTION

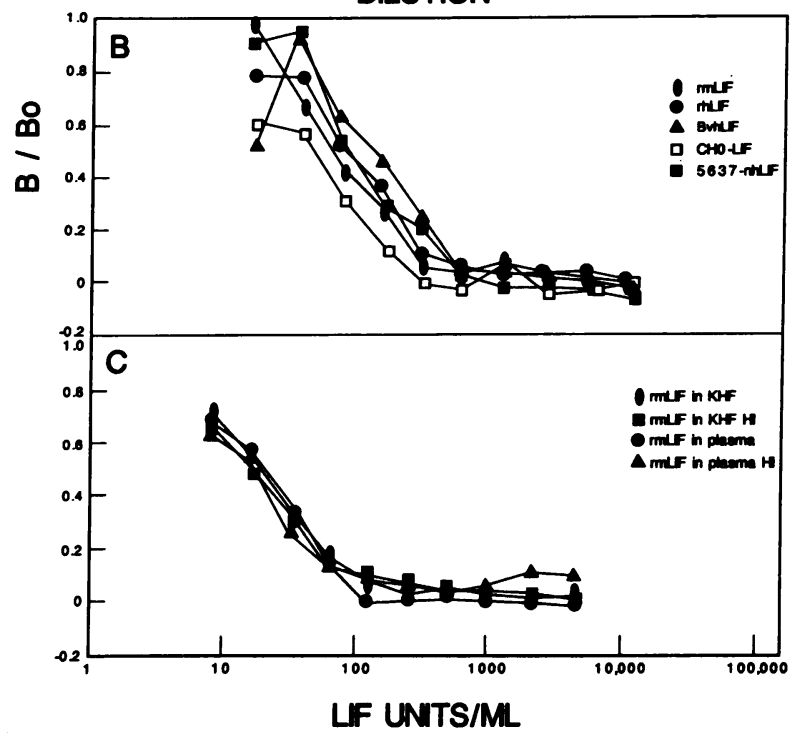

Figure 1. LIF RRA specificity and sensitivity. The RRA is based on competition between radiolabeled rmLIF and LIF for binding to the 3T3-L 1 cell surface LIF receptors. $B / B_{0}$ represents the ratio of ${ }^{125} \mathrm{I}$ rmLIF bound in the presence of competitor $(B)$ to that in the absence of competitor $\left(B_{0}\right)$. (A) Inhibition of ${ }^{125} \mathrm{I}-\mathrm{rmLIF}(330 \mathrm{pM})$ binding by rmLIF ( $2.25 \mathrm{nM})$ but not by rhG-CSF ( $2.25 \mathrm{nM})$, rhGM-CSF (35 nM), rhIL-1 $\alpha(0.28 \mathrm{nM})$, rhTNF- $\alpha(5 \mathrm{nM})$ nor rhIL-6 (12.5 $\mathrm{nM}$ ). (B) Equal inhibition of ${ }^{125} \mathrm{I}$-rmLIF binding by $2.25 \mathrm{nM} E$. coli-derived rmLIF and rhLIF, glycosylated baculovirus-derived rhLIF (BvhLIF), CHO-LIF, and native human LIF (5637-nhLIF). The RRA detected all these forms of LIF with a sensitivity of 100 $\mathrm{U} / \mathrm{ml}$ equivalent to $1 \mathrm{ng} / \mathrm{ml}(45 \mathrm{pM})$. $(C)$ There was no difference in the amount of LIF detected when $1 \mathrm{nM} \mathrm{rmLIF}$ was previously added to RHF or human plasma and heat inactivated (HI) at $56^{\circ} \mathrm{C}$ for $30 \mathrm{~min}$. Concentrations shown are the final concentrations. The specific activities for the various forms of LIF were $10^{8} \mathrm{U} / \mathrm{mg}$ of protein, and the core protein has a mol wt of 22,000 .

from the patient's medical records. Subjects were selected on the premise that they had diseases or conditions in which LIF might be expected to be present, based on its known in vitro biological actions and pathologic effects in mice. Also included were serum samples from 54 pregnant women, 18 neonatal cord blood samples, and serum or plasma from subjects who had had concurrently collected LIF-containing body cavity fluids. Samples were obtained at random times during the course of the subjects' illnesses, or during pregnancy. LIF had not been detected in the serum or plasma of 868 uncharacterized subjects in a previous survey (Waring, P., unpublished observations).

Seven subjects, all children, had detectable serum LIF concentrations. All were in clinical shock at the time of sample
Table I. Summary of Body Fluids Screened for LIF by the RRA

\begin{tabular}{lcc}
\hline \multicolumn{1}{c}{ Fluid } & $\begin{array}{c}\text { No. of } \\
\text { subjects }\end{array}$ & $\begin{array}{r}\text { No. of } \\
\text { positive } \\
\text { subjects }\end{array}$ \\
\hline Plasma/serum & $494^{*}$ & $7(1)$ \\
Urine & 205 & $8(2)$ \\
Cerebrospinal fluid & 454 & $12(5)$ \\
Pericardial fluid & 5 & $5(1)$ \\
Pleural fluid & 53 & $27(3)$ \\
Peritoneal fluid & 52 & $17(4)$ \\
Peritoneal dialysis fluid & 13 & 2 \\
Amniotic fluid & 161 & $17(4)$ \\
Ovarian cyst fluid & 53 & $16(2)$ \\
Tubal cyst fluid & 5 & 2 \\
Breast cyst fluid & 2 & 2 \\
Synovial fluid & 19 & $3(1)$ \\
Seminal fluid & 34 & 0 \\
Aqueous humor & 4 & 0 \\
Hydrocele fluid & 1 & 1 \\
Total & 1,510 & $119(23)$
\end{tabular}

* Includes 45 subjects with LIF-containing body fluids. Numbers in parentheses indicate the number of positive cases not confirmed by M1 assay, due to insufficient sample volume or cytotoxic effect on M1 cells.

collection, six with septic shock, as defined by Bone (31), due to Neisseria meningitidis (four cases, all survived) or Escherichia coli (two cases, both fatal). Serum LIF concentrations in the first blood sample taken after hospital admission ranged from 2 to $205 \mathrm{ng} / \mathrm{ml}$ (Fig. 3). The seventh subject had fulminant hepatic failure with a plasma aspartate aminotransferase concentration of 19,000 IU/liter and a plasma LIF concentration of $16 \mathrm{ng} / \mathrm{ml}$. Shock was associated with disseminated intravascular coagulation and a post-mortem examination revealed idiopathic diffuse hepatic necrosis.

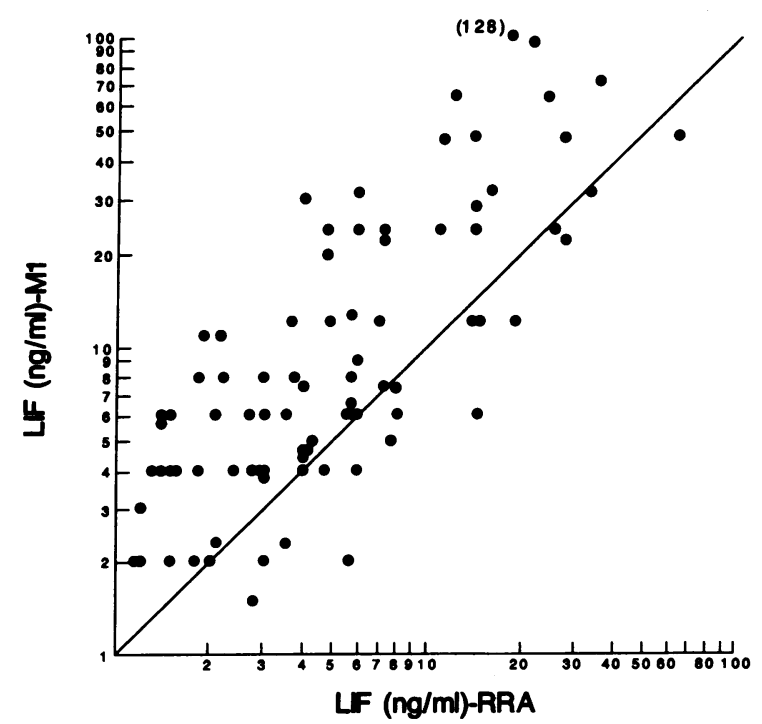

Figure 2. Comparison of LIF concentrations obtained by RRA and M1 bioassay. Titers obtained from positive human body fluid samples assayed by LIF RRA and M1 assay $(r=0.663)$. Solid line is the line of identity. 
Table II. Summary of Clinical Details for Subjects Whose Serum or Plasma Was Screened for LIF

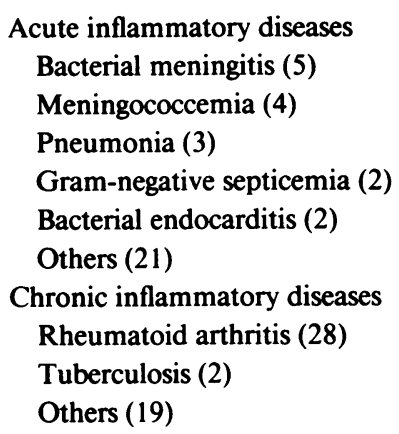

\author{
Neoplasia \\ Carcinoma (53) \\ Lymphoma (42) \\ Leukemia (40) \\ Others (17) \\ Miscellaneous \\ Thrombocytopenia (37) \\ Thrombocytosis (28) \\ Hypercalcemia (28) \\ Myelofibrosis (10) \\ Acute liver failure (3) \\ Others (33)
}

Infective and malignant diagnoses were established by microbiologic and hematologic, histopathologic, or cytopathologic criteria, respectively. Patients with rheumatoid arthritis were diagnosed clinically, using the American Rheumatology Association criteria. Thrombocytopenia and thrombocytosis were defined as platelet counts of $<50$ $\times 10^{9} /$ liter and $>500 \times 10^{9} /$ liter, respectively. Hypercalcemia was defined as an adjusted plasma calcium concentration of $>2.65$ $\mathrm{mmol} / \mathrm{liter}$. Myelofibrosis was defined on the basis of bone marrow trephine examination. Acute liver failure was defined clinically and on the basis of abnormal liver function studies. Numbers in parentheses indicate the number of subjects assayed.

Both subjects with fatal Escherichia coli septic shock had recently developed pancytopenia after chemotherapy for relapsed Ewing's sarcoma and acute lymphoblastic leukemia, respectively. The first subject had markedly elevated serum LIF concentrations $(205 \mathrm{ng} / \mathrm{ml}) 10 \mathrm{~h}$ after onset of sepsis and died $8 \mathrm{~h}$ later. The other subject had high serum LIF concentrations (> $40 \mathrm{ng} / \mathrm{ml}$ ) at presentation and developed severe hemolysis, coagulopathy, ascites (the peritoneal fluid LIF concentration was $>40 \mathrm{ng} / \mathrm{ml}$ ), and renal and hepatic failure. Both subjects were clinically in remission at the onset of sepsis. One of the

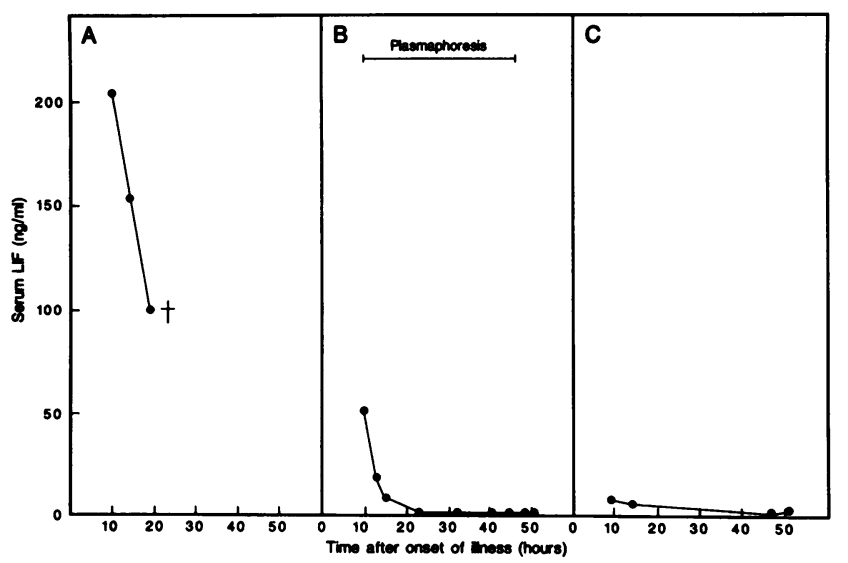

Figure 3. Plasma LIF concentrations in subjects with septic shock. Subject A had fatal Escherichia coli septicemia. The fall in LIF concentration may reflect hemodilution due to resuscitation with intravenous fluids. ${ }^{\dagger}$ Time of death. Subjects $B$ and $C$ both had meningococcal septicemia. The fall in LIF levels in subject B was probably due to hemodilution and the effect of plasmafiltration. subjects with meningococcal septic shock also had high serum LIF concentrations ( $>50 \mathrm{ng} / \mathrm{ml}$ ) at presentation and developed pleural effusions, ascites, disseminated intravascular coagulation, hypercalcemia, and acute renal failure, during which high urinary LIF concentrations $(>40 \mathrm{ng} / \mathrm{ml}$ ) were detected. The other three cases of meningococcemia had low serum LIF concentrations $(2-8 \mathrm{ng} / \mathrm{ml})$ and relatively uncomplicated courses. All four subjects with meningococcemia had been previously well.

LIF was not detected in the concurrently collected plasma and/or serum samples obtained from 45 of 112 subjects, to be described below, with LIF-containing body cavity fluids.

Urine. Urine samples were obtained at random from 175 subjects with suspected urinary tract infection or malignancy, and from subjects with renal failure or metabolic and other disorders, and from 30 pregnant women. Urinary LIF was detected in eight subjects (Fig. 4), including three with urinary tract infection, one with idiopathic macroscopic hematuria, a child with Gitleman's syndrome ( $\mathrm{Mg}, \mathrm{Ca}$, and K-losing nephropathy), a neonate with diabetes mellitus and sepsis, a subject with acute renal failure, and the child with meningococcemia, as discussed above.

Cerebrospinal fluids. Cerebrospinal fluid samples were collected consecutively from 451 subjects who had undergone spinal puncture for investigation of suspected meningitis (106 cases ), cerebrospinal leukemic infiltration ( 77 cases), and neurological and other miscellaneous, unknown, or undiagnosed disorders (Fig. 4). Three samples were also obtained from subdural effusions. There were 12 cases of proven meningitis caused by Haemophilus influenzae type b (seven cases), Streptococcus pneumoniae (two cases), Escherichia coli (one case), Neisseria meningitidis (one case), and Coxsackie virus (one case). Six of the patients with bacterial meningitis had detectable cerebrospinal fluid LIF concentrations at the time of presentation. Another patient had an LIF-containing postmeningitis subdural effusion.

Three of the septicemic subjects with elevated serum LIF concentrations had concurrently collected cerebrospinal fluid. None had meningitis and LIF was not detected in their cerebrospinal fluid, indicating that LIF does not cross the intact bloodbrain barrier and confirming previous results in mice (32).
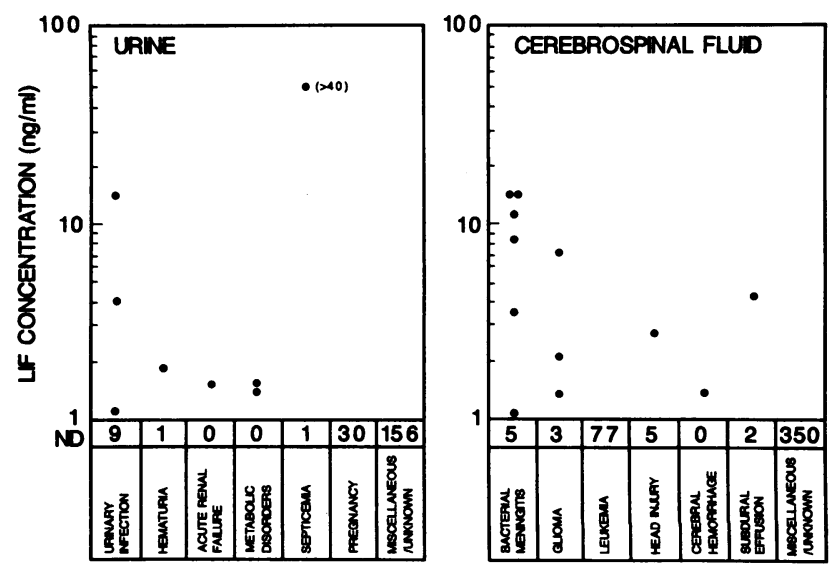

Figure 4. Urinary and cerebrospinal fluid LIF concentrations. (ND, not detected). Numbers below the line representing the limit of detection $(1 \mathrm{ng} / \mathrm{ml})$ indicate the number of subjects in each disease category in whose fluid LIF was not detected. 
Two subjects had detectable cerebrospinal fluid LIF concentrations in bloodstained fluids, after a traumatic frontal contusion and an intraventricular rupture of a hypertensive thalamic hemorrhage. There were six subjects with gliomas, two of whom had malignant astrocytomas and elevated cerebrospinal fluid LIF concentrations. Fluid from a cystic cerebral ependymoma also contained LIF.

Coelomic cavity effusions. Fluid was collected consecutively from 110 subjects with effusions due to a variety of causes, and peritoneal dialysis fluid was obtained from subjects receiving ambulatory dialysis for renal failure (Fig. 5). Low LIF concentrations (arbitrarily designated as $1-10 \mathrm{ng} / \mathrm{ml}$ ) were occasionally present in effusions due to cardiac failure or alcoholic ascites, and were commonly found in chronic inflammatory or reactive processes, and in malignant effusions. Moderately elevated LIF concentrations $(>10 \mathrm{ng} / \mathrm{ml})$ were present in effusions associated with acute inflammatory conditions such as pneumonia, pneumococcal pericarditis (one case, containing $14 \mathrm{ng} / \mathrm{ml}$ ), a hydrocele associated with epididymoorchitis (one case, containing $11.2 \mathrm{ng} / \mathrm{ml}$ ), and in rheumatoid pleural effusions associated with active polyserositis. High LIF concentrations were also present in heavily bloodstained peritoneal fluid from a case with fatal mesenteric infarction (64 $\mathrm{ng} / \mathrm{ml})$.

Amniotic fluid. Amniotic fluid was obtained consecutively from 126 subjects ( 109 with normal pregnancies) by amniocentesis performed between 14 and 19 wks gestation and none contained detectable LIF. Liquor was collected transvaginally from 35 women in labor at 30-42 wks gestation, of which 16 samples contained less than $5 \mathrm{ng} / \mathrm{ml}$ of LIF (Fig. 6). One case with proven chorioamnionitis associated with premature rupture of membranes had moderately elevated amniotic LIF concentrations $(20 \mathrm{ng} / \mathrm{ml})$.

Cyst fluids. Fluid samples were obtained consecutively from 60 cysts, including 53 ovarian cysts, 5 tubal cysts, and 2 breast cysts, by percutaneous, transvaginal, or perioperative aspiration, or from resected surgical specimens. Sixteen of the ovarian cyst fluids had low LIF concentrations (Fig. 6) that were not confined to particular cyst types. Very high LIF concentrations were present in fluid from a "pseudocyst" asso-

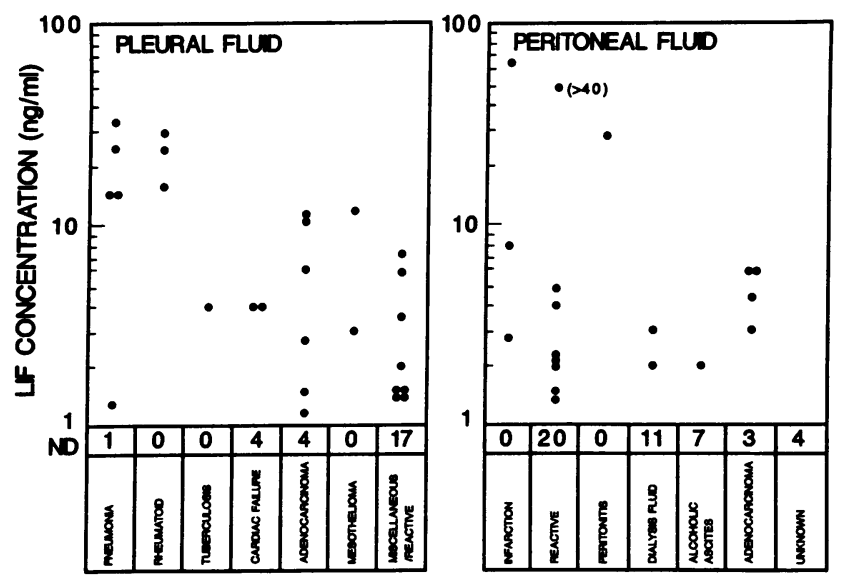

Figure 5. Pleural and peritoneal effusion fluid LIF concentrations. (ND, not detected). Numbers below the line representing the limit of detection $(1 \mathrm{ng} / \mathrm{ml})$ indicate the number of subjects in each disease category in whose fluid LIF was not detected.
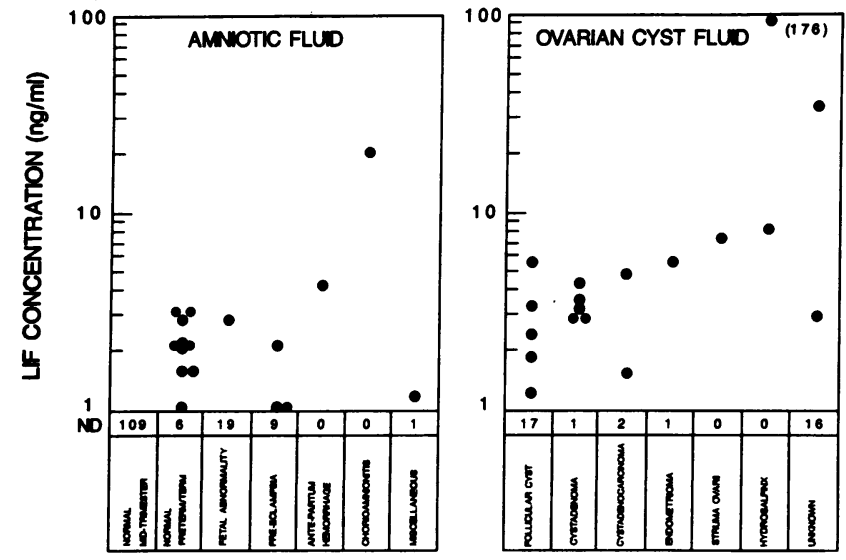

Figure 6. Amniotic and ovarian cyst fluid LIF concentrations. (ND, not detected). Numbers below the line representing the limit of detection $(1 \mathrm{ng} / \mathrm{ml})$ indicate the number of subjects in each disease category in whose fluid LIF was not detected.

ciated with extensive pelvic inflammatory disease (176 ng/ $\mathrm{ml}$ ). Two benign breast cyst fluids had detectable LIF concentrations ( 5.4 and $21.6 \mathrm{ng} / \mathrm{ml})$.

Synovial fluid. Synovial fluid samples were collected from 19 subjects with knee joint effusions due to rheumatoid arthritis (seven cases), psoriatic arthritis (four cases), gout (two cases), juvenile chronic arthritis ( two cases), multicentric reticulohistiocytosis (two cases), and unspecified inflammatory arthritis (two cases). Low LIF concentrations were detected $(1.5-6 \mathrm{ng} / \mathrm{ml})$ in synovial fluids from three subjects, one with rheumatoid arthritis, another with psoriatic arthritis, and a child with juvenile chronic arthritis.

\section{Discussion}

The advantages of the LIF RRA over the M1 bioassay and LIF radioimmunoassay are, respectively, its specificity and ability to detect biologically active LIF. The level of sensitivity of the RRA however is less than that of radioimmunoassays available for many cytokines and it is possible that low but abnormally elevated levels of LIF may well be detectable by such methods in a number of disease states that were negative in this study.

In general, there was fairly close concordance between the LIF RRA and M1 assay results, which would be expected because both require LIF binding to the same cell-surface LIFR. The higher values generally obtained with the M1 assay may be due to the repeated selection in our laboratory of M1 cell subclones with greater sensitivity to LIF. Some of the samples, however, had unexpectedly high titers with the M1 assay, compared to the LIF RRA (Fig. 2), possibly due to the concurrent presence of high concentrations of IL-6. Concentrations of OSM ( $25 \mathrm{nM}$ ) capable of inducing maximal differentiation of M1 cells (data not shown) showed no competition with ${ }^{125} \mathrm{I}$ rmLIF binding to 3T3-L1 cells, suggesting that, in contrast to its actions on M1 cells (33), OSM does not bind to high affinity LIF receptors on 3T3-L1 cells.

LIF, like IL-1, IL-6, and TNF- $\alpha$ (34-37), was detected in the serum of subjects with Gram-negative and meningococcal septic shock. The significance of this finding is further supported by the results of in vivo experiments in mice that had elevated serum LIF concentrations $2-3 \mathrm{~h}$ after intravenous in- 
jection of LPS (38). The pathogeneic role of LIF in septic shock is unknown; however, mice injected with high doses of rmLIF died within 3-4 d (12), suggesting that LIF may contribute to the mortality of septicemic patients. The failure to detect LIF in the serum or plasma of the subjects with positive body fluids is probably due to the rapid metabolism, excretion, or inactivation of LIF released into the circulation. In mice the serum half-life of LIF is $\sim 8 \mathrm{~min}$ (12).

Biologically active LIF was detected in the urine at high concentration in a child with meningococcemia, suggesting that renal clearance of circulating LIF is the major route of excretion. However, iodinated inactive LIF breakdown products were present in the urine of mice injected with ${ }^{125} \mathrm{I}$-rmLIF (32). The demonstration of low concentrations of LIF in the urine of subjects with renal and metabolic disorders suggests that the normal mechanism of LIF metabolism, or excretion, was somehow altered in these subjects. Urinary LIF was also found in three subjects with urinary infections, raising the possibility of local LIF production by inflammatory cells within the urinary tract. LIF has recently also been detected in the urine of patients with acute renal transplant rejection (39).

The detection of elevated concentrations of LIF in acute inflammatory exudates is similar to that of other proinflammatory cytokines. Several cytokines including IL-1 (1), G-CSF (40), IL-6 (41), and TNF- $\alpha$ (42), have been reported in cerebrospinal fluid in patients with bacterial meningitis. IL-1 (43), TNF (44), and IL-6 (45) have been found in elevated concentrations in amniotic fluid from women with intraamniotic infection, and IL- $1 \alpha$, IL-6, IL-8, TNF- $\alpha$, TGF- $\beta$, M-CSF, and GM-CSF are commonly found in synovial fluid in patients with rheumatoid arthritis (46). The most likely cellular sources of LIF in these fluids include fluid inflammatory cells, especially macrophages, or the lining inflammatory cells and fibroblasts, all known to be capable of producing LIF in vitro. In malignant effusions the tumor cells may secrete LIF, but the concentrations detected are also consistent with LIF being produced by the accompanying reactive cells.

The biological role of LIF in these predominantly inflammatory body fluids is not readily explained by its currently known actions, and it is unknown whether LIF contributes to, or is a response to, local tissue damage. LIF was occasionally detected in high concentration in bloodstained fluids following trauma or infarction, suggesting that LIF may be released in response to tissue damage. LIF, like IL-1, IL-6, and TNF- $\alpha$ may be responsible for some of the systemic effects such as acute phase response, fever, thrombocytosis, and elevated erythrocyte sedimentation rate seen in diseases such as rheumatoid arthritis. Serum concentrations capable of inducing these responses would have to be relatively low or transiently elevated, because LIF was not detected in the serum of subjects with diseases commonly associated with these systemic manifestations. Likewise, LIF was not detected in the serum of subjects with malignancy, hypercalcemia, myelofibrosis, thrombocytosis, and other disorders that might be expected to be associated with LIF, on the basis of its known pathological effects in mice $(12,14,47,48)$.

We have shown that high circulating LIF concentrations were present in six subjects with septic shock and that the degree of elevation appeared to be related to the severity of disease. The hemodynamic and metabolic effects of these high LIF concentrations and their possible role in the pathogenesis of septic shock are unknown. In inflammatory foci, LIF ap- pears to be primarily a locally acting molecule, with the circulating concentrations being maintained at low levels, presumably to prevent unwanted systemic effects. Prospective studies aimed at testing the significance of some of these associations are being performed.

\section{Acknowledgments}

We thank the following people for providing or allowing access to patient samples: Maryann Arnstein, Barbara Bell, Gary Clarke, Michael Coote, David Deams, John Earle, Mary Harney, Gawdat Ibrahim, Katharine McGrath, Mark Pertile, Lyn Waring, and the midwives of the Royal Women's Hospital. We also appreciate the assistance of John Pye in performing the phosphorimager readings, and of Ian Campbell in kindly providing some of the recombinant human cytokines.

We also acknowledge the support received from The National Health and Medical Research Council, Canberra, Australia; AMRAD Corporation and the Anti-Cancer Council of Victoria, Melbourne, Australia; and the National Institutes of Health (under grant CA22556), Bethesda, MD.

\section{References}

1. Dinarello, C. A. 1991. Interleukin-1 and Interleukin-1 antagonism. Blood. 77:1627-1652.

2. Le, J., and J. Vilček. 1987. Tumor necrosis factor and interleukin 1: cytokines with multiple overlapping biological activities. Lab. Invest. 56:234-248.

3. Hirano, T., S. Akira, T. Taga, and T. Kishimoto. 1990. Biological and clinical aspects of interleukin 6. Immunol. Today. 11:443-449.

4. Tomida, M., Y. Yamamoto-Yamaguchi, and M. Hozumi. 1984. Purification of a factor inducing differentiation of mouse myeloid leukemic M1 cells from conditioned medium of mouse fibroblast $\mathrm{L} 929$ cells. J. Biol. Chem. 259:10978-10982.

5. Metcalf, D., D. J. Hilton, and N. A. Nicola. 1988. Clonal analysis of the actions of the murine leukemia inhibitory factor on leukemic and normal murine hemopoietic cells. Leukemia (Baltimore). 2:216-221.

6. Ishimi, Y., C. Miyaura, C. H. Jin, T. Akatsu, E. Abe, Y. Nakamura, A. Yamaguchi, S. Yoshiki, T. Matsuda, T. Hirano et al. 1990. IL-6 is produced by osteoblasts and induces bone resorption. J. Immunol. 145:3297-3303.

7. Baumann, H., and G. G. Wong. 1989. Hepatocyte-stimulating factor III shares structural and functional identity with leukemia inhibitory factor. J. Im munol. 143:1163-1167.

8. Abe, E., H. Tanaka, Y. Ishimi, C. Miyaura, T. Hayashi, H. Nagasawa, M. Tomida, Y. Yamaguchi, M. Hozumi, and T. Suda. 1986. Differentiation-inducing factor purified from conditioned medium of mitogen-treated spleen cell cultures stimulates bone resorption. Proc. Natl. Acad. Sci. USA. 83:5958-5962.

9. Yamamori, T., K. Kukada, R. Aebersold, S. Korsching, M-J. Fann, and P. H. Patterson. 1989. The cholinergic neuronal differentiation factor from heart cells is identical to leukemia inhibitory factor. Science (Wash. DC). 246:14121416.

10. Murray, R., F. Lee, and C-P. Chiu. 1990. The genes for leukemia inhibitory factor and interleukin- 6 are expressed in mouse blastocysts prior to the onset of hemopoiesis. Mol. Cell. Biol. 10:4953-4956.

11. Metcalf, D., D. Hilton, and N. A. Nicola. 1991. Leukemia inhibitory factor can potentiate murine megakaryocyte production in vitro. Blood. 77:2150-2153.

12. Metcalf, D., N. A. Nicola, and D. P. Gearing. 1990. Effects of leukemia inhibitory factor on hematopoietic and other tissues in mice. Blood. 76:50-56.

13. Mori, M., K. Yamaguchi, and K. Abe. 1989. Purification of a lipoprotein lipase-inhibiting protein produced by a melanoma cell line associated with cancer cachexia. Biochem. Biophys. Res. Commun. 160:1085-1092.

14. Mori, M., K. Yamaguchi, S. Honda, K. Nagasaki, M. Ueda, O. Abe, and K. Abe. 1991. Cancer cachexia syndrome developed in nude mice bearing melanoma cells producing leukemia-inhibitory factor. Cancer Res. 51:6656-6659.

15. Gearing, D. P., C. J. Thut, T. VandenBos, S. D. Gimpel, P. B. Delaney, J. King, V. Price, D. Cosman, and M. P. Beckmann, 1991. Leukemia inhibitory factor receptor is structurally related to the IL-6 signal transducer, gp 130. EMBO (Eur. Mol. Biol. Organ.) J. 10:2839-2848.

16. Hilton, D. J., N. A. Nicola, and D. Metcalf. 1988. Specific binding of murine leukemia inhibitory factor to normal and leukemic monocytic cells. Proc. Natl. Acad. Sci. USA. 85:5971-5975.

17. Metcalf, D. 1991. The leukemia inhibitory factor (LIF). Int. J. Cell. Cloning. 9:95-108.

18. Godard, A., D. Heymann, S. Raher, I. Anegon, M.-A. Peyrat, B. Le Mauff, 
E. Mouray, M. Gregoire, K. Virdee, J.-P. Soulillou et al. 1992. High and low affinity receptors for human interleukin for DA cell/leukemia inhibitory factor on human cells. Molecular characterization and cellular distribution. J. Biol. Chem. 267:3214-3222.

19. Hilton, D. J., N. A. Nicola, D. Metcalf. 1991. Distribution and characterization of receptors for LIF on haemopoietic and hepatic cells. J. Cell. Physiol. 146:207-215.

20. Gearing, D., M. R. Comeau, D. J. Friend, S. D. Gimpel, C. J. Thut, J. McCourty, K. K. Brasher, J. A. King, S. Gillis, B. Mosley et al. 1992. The IL-6 signal transducer, gp 130: An oncostatin M receptor and affinity converter for the LIF receptor. Science (Wash. DC). 255:1434-1437.

21. Bhatt, H., L. J. Brunet, and C. L. Stewart. 1991. Uterine expression of leukemia inhibitory factor coincides with the onset of blastocyst implantation. Proc. Natl. Acad. Sci. USA. 88:11408-11412.

22. Lubbert, M., L. Mantovani, A. Lindemann, R. Mertelsmann, and F. Herrmann. 1991. Expression of leukemia inhibitory factor is regulated in human mesenchymal cells. Leukemia (Baltimore). 5:361-365.

23. Gascan, H., I. Anegon, V. Praloran, J. Naulet, A. Godard, J.-P. Soulillou, and Y. Jacques. 1990. Constitutive production of human interleukin for DA cells/Leukemia inhibitory factor by human tumor cell lines derived from various tissues. J. Immunol. 144:2592-2598.

24. Miyaura, C., K. Onozaki, Y. Akiyama, T. Taniyama, T. Hirana, T. Kishimoto, and T. Suda. 1988. Recombinant human interleukin 6 (B-cell stimulatory factor 2 ) is a potent inducer of differentiation of mouse myeloid leukemia cells (M1). FEBS (Fed. Eur. Biochem. Soc.) Lett. 234:17-21.

25. Tomida, M., Y. Yamamoto-Yamaguchi, M. Hozumi, T. Okabe, and F. Takaku. 1986. Induction by recombinant human granulocyte colony-stimulating factor of differentiation of mouse myeloid leukemic M1 cells. FEBS (Fed. Eur. Biochem. Soc.) Lett. 207:271-275.

26. Rose, T. M., and A. G. Bruce. 1991. Oncostatin $\mathbf{M}$ is a member of a cytokine family that includes leukemia-inhibitory factor, granulocyte colonystimulating factor, and interleukin 6. Proc. Natl. Acad. Sci. USA. 88:8641-8645.

27. Williams, R. L., D. J. Hilton, S. Pease, T. A. Willson, C. L. Stewart, D. P. Gearing, E. F. Wagner, D. Metcalf, N. Nicola, and N. M. Gough. 1988. Myeloid leukaemia inhibitory factor maintains the development of embryonic stem cells. Nature (Lond.). 336:684-687.

28. Matsui, Y., D. Toksoz, S. Nishikawa, S-I. Nishikawa, D. Williams, K. Zsebo, and B. L. M. Hogan. 1991. Effect of Steel factor and leukaemia inhibitory factor on murine primordial germ cells in culture. Nature (Lond.). 353:750-752.

29. Hilton, D. J., and N. A. Nicola. 1992. Kinetic analyses of the binding of leukemia inhibitory factor to receptors on cells and membranes and in detergent solution. J. Biol. Chem. 267:10238-10247.

30. Nie, N. H., C. H. Hull, J. G. Jenkins, K. Steinbrenner, and D. H. Bent. 1975. Statistical package for the social sciences. 2nd ed. McGraw-Hill Book Company, New York. 280-288.

31. Bone, R. C. 1991. Sepsis, the sepsis syndrome, multi-organ failure: a plea for comparable definitions. Ann. Intern. Med. 114:332-333.

32. Hilton, D. J., N. A. Nicola, P. M. Waring, and D. Metcalf. 1991. The clearance and fate of leukemia-inhibitory factor (LIF) after injection into mice. J. Cell. Physiol. 148:430-439.

33. Gearing, D. P., and A. G. Bruce. 1992. Oncostatin M binds to the high-affinity leukemia inhibitory factor receptor. New Biol. 4:61-65.
34. Girardin, E., G. E. Grau, J.-M. Dayer, P. Roux-Lombard, P.-H. Lambert, and the J5 Study Group. 1988. Tumor necrosis factor and interleukin-1 in the serum of children with severe infectious purpura. New Engl. J. Med. 319:397400.

35. Waage, A., A. Halstensen, and T. Espevik. 1987. Association between tumour necrosis factor in serum and fatal outcome in patients with meningococcal disease. Lancet. i:355-357.

36. Waage, A., P. Brandtzaeg, A. Halstensen, P. Kierulf, and T. Espevik. 1989. The complex pattern of cytokines in serum from patients with meningococcal septic shock. Association between interleukin 6, interleukin 1, and fatal outcome. J. Exp. Med. 169:333-338.

37. Calandra, T., J. Gerain, D. Heumann, J.-D. Baumgartner, M. P. Glauser, and the Swiss-Dutch J5 Immunoglobulin Study Group. 1991. High circulating levels of interleukin-6 in patients with septic shock: evolution during sepsis, prognostic value, and interplay with other cytokines. Am. J. Med. 91:23-29.

38. Metcalf, D. 1989. Suppression of myeloid leukemic cells by normal hemopoietic regulators. In Proceedings of the First International Mochida Memorial Symposium: Recent Progress in Cytokine Research. Y. Yamamura, editor. Mochida Memorial Foundation for Medical Research and Pharmaceutical Research, Tokyo. 119-134.

39. Taupin, J. L., D. Morel, J. P. Moreau, N. Gualde, L. Potaux, and J.-H Bezian. 1992. HILDA/LIF urinary excretion during acute kidney rejection. Transplantation (Baltimore). 53:655-658.

40. Shimoda, K., S. Okamura, F. Omori, Y. Mizuno, T. Hara, T. Aoki, K. Ueda, and Y. Niho. 1991. Granulocyte colony-stimulating factor in cerebrospinal fluid from patients with meningitis. Blood. 77:2214-2217.

41. Houssiau, F. A., K. Bukasa, C. J. M. Sindic, J. Van Damme, and J. Van Snick. 1988. Elevated levels of the $26 \mathrm{~K}$ human hybridoma growth factor (interleukin 6) in cerebrospinal fluid of patients with acute infection of the central nervous system. Clin. Exp. Immunol. 71:320-323.

42. Leist, T. P., K. Frei, S. Kam-Hansen, R. M. Zinkernagel, and A. Fontana. 1988. Tumor necrosis factor $\alpha$ in cerebrospinal fluid during bacterial, but not viral, meningitis. Evaluation in murine model infections and in patients. J. Exp. Med. 167:1743-1748.

43. Romero, R., D. T. Brody, E. Oyarzun, M. Mazor, Y. K. Wu, J. C. Hobbins, and S. K. Duram. 1989. Infection and labor. III. Interleukin-1: a signal for the onset of parturition. Am. J. Obstet. Gynecol. 160:1117-1123.

44. Romero, R., K. R. Manogue, M. D. Mitchell, Y. K. Wu, E. Oyarzun, J. C. Hobbins, and A. Cerami. 1989. Infection and labour IV. Cachectin-tumor necrosis factor in the amniotic fluid of women with intraamniotic infection and preterm labour. Am. J. Obstet. Gynecol. 161:336-341.

45. Romero, R., C. Avila, U. Santhanam, and P. B. Sehgal. 1990. Amniotic fluid interleukin 6 in preterm labor. Association with infection. J. Clin. Invest. 85:1392-1400.

46. Arend, W. P., and J.-M. Dayer. 1990. Cytokines and cytokine inhibitors or antagonists in rheumatoid arthritis. Arthritis Rheum. 33:305-315.

47. Metcalf, D., and D. P. Gearing. 1989. A myelosclerotic syndrome in mice engrafted with cells producing high levels of leukemia inhibitory factor (LIF). Leukemia (Baltimore). 3:847-852.

48. Metcalf, D., and D. P. Gearing. 1989. Fatal syndrome in mice engrafted with cells producing high levels of the leukemia inhibitory factor. Proc. Natl. Acad. Sci. USA. 86:5948-5952. 